\title{
Predominance Diagrams of Spent Nuclear Fuel Materials in LiCl-KCl and NaCl-KCl Molten Salt Eutectics
}

\author{
Rema Abdulaziz, Leon D. Brown, Douglas Inman, Stefaan Simons, Paul R. Shearing and \\ Daniel J. L. Brett* \\ Electrochemical Innovation Lab, Department of Chemical Engineering, University College London, \\ Torrington Place, London, WC1E 7JE, United Kingdom \\ *E-mail: d.brett@ucl.ac.uk
}

doi: $10.20964 / 2016.12 .27$

Received: 27 April 2016 / Accepted: 25 September 2016 / Published: 10 November 2016

Predominance phase diagrams for metal-molten salt systems are diagrams of potential vs. the negative logarithm of the activity of $\mathrm{O}^{2-}$ ions $\left(E-p \mathrm{O}^{2-}\right)$; they are a valuable tool for predicting and understanding electrochemical systems and for optimising process conditions. Here, predominance diagrams are produced for the range of nuclear spent materials $(\mathrm{U}, \mathrm{Pu}, \mathrm{Np}, \mathrm{Am}, \mathrm{Cm}, \mathrm{Cs}, \mathrm{Nd}, \mathrm{Sm}, \mathrm{Eu}, \mathrm{Gd}, \mathrm{Mo}, \mathrm{Tc}$, $\mathrm{Ru}, \mathrm{Rh}, \mathrm{Ag}$ and $\mathrm{Cd}$ species), in both $\mathrm{LiCl}-\mathrm{KCl}$ at $500{ }^{\circ} \mathrm{C}$ and $\mathrm{NaCl}-\mathrm{KCl}$ at $750{ }^{\circ} \mathrm{C}$. The two salt eutectics were chosen as they are the two main systems used for pyroprocessing; temperatures were selected within each salts normal operating range. All of the diagrams presented show regions of stability for the different metal species, their oxides and chlorides at unit activity; however, this activity can be altered in accordance with the equations derived. Examples of selective electrochemical reduction are also demonstrated for potential spent fuel reprocessing in both salt systems.

Keywords: Predominance diagrams; Spent fuel; Nuclear materials; Molten salts; Pyroprocessing.

\section{$\underline{\text { FULL TEXT }}$}

(C) 2016 The Authors. Published by ESG (www.electrochemsci.org). This article is an open access article distributed under the terms and conditions of the Creative Commons Attribution license (http://creativecommons.org/licenses/by/4.0/). 